\title{
Hemoglobin-associated proteins isolated from blood serum of Ehrlich carcinoma-bearing mice
}

\author{
F.V.DONENKO ${ }^{1}$, S.M. SITDIKOVA ${ }^{1}$, A.V. SYRTSEV ${ }^{1}$, A.T. GRADYUSHKO ${ }^{1}$, \\ M.V. KISELEVSKY ${ }^{1}$, M.V. SEREBRYAKOVA ${ }^{2}$ and T. EFFERTH ${ }^{3}$ \\ ${ }^{1}$ N.N. Blokhin Russian Cancer Research Center, ${ }^{2}$ Orekhovich Institute of \\ Biomedical Chemistry, Russian Academy of Medical Sciences, Moscow, Russia; \\ ${ }^{3}$ German Cancer Research Center, Pharmaceutical Biology, Heidelberg, Germany
}

Received September 17, 2007; Accepted November 16, 2007

\begin{abstract}
In the present study, we analyzed differential composition of blood serum from Ehrlich carcinoma-bearing and healthy male C57B1/6 mice by isolating complexes of hemoglobin and other serum proteins by a proteomic approach (gel filtration, gel electrophoresis, and mass spectrometry). The hemoglobin fractions isolated from the serum of micebearing tumors contained several proteins with molecular weights of $15,65,68$, and $100 \mathrm{kDa}$, while hemoglobin fractions isolated from the serum of healthy mice did not contain additional protein bands. These bands were identified by MALDI-TOF as haptoglobin, serum albumin, a homologue of $\alpha$-fetoprotein, and hemoglobin- $\alpha$. Ion exchange chromatography indicated complex formation of these proteins. Injection of hemoglobin-associated blood serum proteins (HAP) isolated from tumor-bearing animals, leads to tumor regression. Intraperitoneally injected HAP-induced apoptosis in Ehrlich carcinoma cells but not normal peritoneal cells and led to a complete regression of the ascitic or solid Ehrlich carcinoma. A one-year follow up of the animals did not reveal any signs of tumor growth. In conclusion, HAP might be a novel principle of tumor regression. The clinical relevance of these findings with Ehrlich carcinoma should be investigated in the future.
\end{abstract}

\section{Introduction}

The immune and humoral systems play eminent roles for cell to cell or cell to organ communication in higher organisms. Aberrant signaling in both systems causes diseases. The link

Correspondence to: Dr Thomas Efferth, German Cancer Research Center, Pharmaceutical Biology (C015), Im Neuenheimer Feld 280, 69120 Heidelberg, Germany

E-mail: t.efferth@dkfz.de

Key words: $\alpha$-fetoprotein, anti-tumor activity, apoptosis, hemoglobin, proteomics between these two signaling routes and cancer has been a matter of research for many years. Despite considerable progress, the understanding of the interplay between normal defense mechanisms of the body and tumor growth is still incomplete. It is known for many decades that the surgical removal of a primary tumor can stimulate the growth of distant metastases (1). It was postulated that growth factors present in blood serum could mediate this effect. The transfer of serum from tumor-bearing animals accelerates metastatic tumor growth in recipient mice (1). In contrast, other investigators found that the transfer of tumor-sensitized cells from one tumor-bearing subject to another confers protection against tumor growth (2-4). While the latter line of research led to modern immunotherapy concepts of adoptive immunotherapy using cytotoxic T-cells (5), the role of serum factors for tumor growth was not developed with the same intensity during the past years.

In our own studies, we showed that surgical removal of Ehrlich carcinoma does not entail a longer survival time of CBA C57Bl/6 mice compared to non-operated tumor-bearing mice (6). While operation of tumors was followed by the development of metastases in $100 \%$ of the animals, metastases were not observed in non-operated tumor-bearing mice. Surprisingly, repeated transplantation of tumor cells (second challenge) did not result in tumor development in operated mice despite metastatic growth derived from the first challenge with tumor cells. This suggests that metastatic growth as well as suppression of second challenge tumors depend on factors present in the blood serum of the host organisms.

While we did not identify specific serum proteins responsible for these effects $(6,7)$, the data of others point to serum proteins, which could affect tumor growth. The transgenic mice strain MMTV-neu (ErbB-2) with transplanted breast cancer showed that the liver of tumor-bearing mice displayed a fetal phenotype with expression of $\alpha$-fetoprotein (AFP) (8). AFP acts as a growth factor and biological response modifier, which affects cell proliferation (9-12). AFP functions as a transporter of various ligands, such as steroid hormones and hemoglobin degradation products (bilirubin) (13-15). Ivanov et al $(16,17)$ reported that peptides resulting from hemoglobin degradation products affect tumor cell proliferation. 
In the present study, we analyzed the differential composition of blood serum from Ehrlich carcinoma-bearing and healthy mice by isolating hemoglobin-associated serum proteins using a proteomic approach (gel filtration, gel electrophoresis, and mass spectrometry). The biological activity of these proteins was analyzed regarding apoptosis and anti-tumor effect in vivo.

\section{Materials and methods}

Tumor and animal experimentation. Ascitic Ehrlich carcinoma (aneuploid strain ELD) was obtained from the bank of tumor strains of the N.N. Blokhin Russian Cancer Research Center (Moscow, Russia). Cells were transplanted intraperitoneally (i.p.) to obtain ascitic tumors or by intramuscular injection (i.m.) to obtain solid tumors into the right hind limb of C57Bl/ 6 mice (1x10 cells/mouse diluted in $100 \mu 1$ RPMI-1640 medium, Panecko, Russia). The experiments were carried out using male, 2-3 months old C57B1/6 mice. The animals were obtained from Stolbovaya Company (Moscow, Russia). The mice received standard laboratory feeding and tap water ad libitum. All experiments were done in accordance with the legal regulations for animal experimentation in Russia and with official permission of the Institute of Experimental Diagnosis and Therapy of Tumors of the N.N. Blokhin Russian Cancer Research Center (18).

To determine the effect of blood serum from tumor-bearing mice, we administered hemoglobin-associated proteins and serum proteins of tumor-bearing or blood serum from healthy mice (100 $\mu \mathrm{g}$ /mouse in $400 \mu 10.9 \% \mathrm{NaCl}$ solution) to other mice bearing i.p. or i.m. transplanted Ehrlich carcinoma cells. The administration was performed i.p. four days after tumor transplantation and repeated 5 times at intervals of $48 \mathrm{~h}$. Each group included 10 animals. Statistical evaluation was done using Fisher's Student test. Difference was reliable with $\mathrm{p}<0.05$.

Protein isolation. Hemoglobin-associated proteins (HAP) were isolated from the blood of mice bearing i.m. transplanted Ehrlich carcinoma, after the tumors reached a size of $>1 \mathrm{~cm}^{3}$. Serum was diluted in 0.01 M Tris buffer $(\mathrm{pH} \mathrm{7.4,0.01 \%}$ sodium azide), transferred on PD-10 columns (Amersham Biosciences, Freiburg, Germany), and left for $12 \mathrm{~h}$ at $4{ }^{\circ} \mathrm{C}$. The precipitate was separated by centrifugation at $1000 \mathrm{x} \mathrm{g}$ for $20 \mathrm{~min}$. Proteins were applied to Sephadex QFF columns. Non-bound serum proteins were eluated by $0.01 \mathrm{M}$ Tris buffer, $\mathrm{pH} 7.4$, with $0.01 \%$ sodium azide, while the bound proteins were eluated by a sodium chloride gradient $(0.5 \mathrm{M}, 0.01 \mathrm{M}$

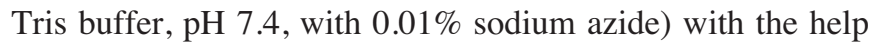
of a GP-250 programmed gradient pump (Pharmacia). Protein elution was monitored in a flow cell at $\lambda=280 \mathrm{~nm}$. The redcolored hemoglobin eluate was monitored visually, and an aliquot was measured at HP 8452 A diode array spectrophotometer and absorption value of $\lambda=414 \mathrm{~nm}$. The isolated hemoglobin complexes were subjected to HW-55F columns (Tosoh Bioscience, Stuttgart, Germany), and the red-stained aliquots were collected. HW-55F columns $(26 \times 56 \mathrm{~cm})$ were calibrated by proteins (urease, catalase, $\gamma$-globulin, albumin, cytochrom c) for detection weight of proteins in eluate. The separation of protein fractions was performed by ion exchange chromatography by Sephadex QFF columns, gel filtration
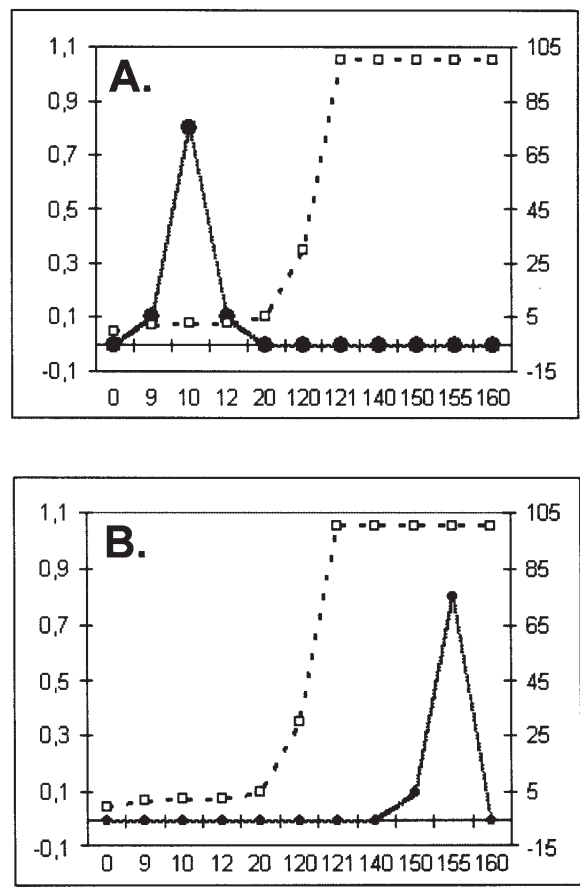

Figure 1. Elution profile of proteins obtained by separation with rephrase QFF columns. (A) Elution profile of hemoglobin healthy mice. (B) Elution profile of hemoglobin of tumor-bearing mice. $\mathrm{X}$-axis, elution volume $(\mathrm{ml})$; $\mathrm{Y}$-axis, absorption at $\lambda=414 \mathrm{~nm}$. A line with black circles, hemoglobin elution; a dashed line with white squares, $\mathrm{NaCl}$ concentration gradient. This experiment was repeated 5 times.

with HW-55F columns, and SDS electrophoresis. MALDITOF-mass spectrometry (19) was used for identification of proteins associated with hemoglobin.

Protein gel electrophoresis. Proteins samples were separated by SDS/PAGE on a $12.5 \%$ gel and stained with Coomassie Blue according to Laemmli (20). Samples subjected to SDS/ PAGE were solubilized in sample buffer, containing $63 \mathrm{mM}$ Tris/HCl, pH 6.8, 10\% (v/v) glycerol, 2\% (w/v) SDS, and $30 \mu \mathrm{M}$ bromophenol blue. 2-Mercaptoethanol 5\% (v/v) was conditionally added to or omitted in the sample buffer. Unless stated otherwise, $12.5 \%$ acrylamide gels, with a bisacrylamide/ acrylamide ratio of 0.8:30, were used. Samples were applied in quantities of $20 \mu \mathrm{g}$ protein/lane to evaluate all components of protein complexes.

MALDI-TOF. Protein strips were cut out from electrophoresis gels, using a Proteome Works spot picking robot (Bio-Rad Laboratories, Hercules, CA, USA). Trypsin-type proteasecleaved peptides were used in the peptide mixtures. Mass spectra were received by means of MALDI-TOF Reflex III mass spectrometers (Bruker, BioSciences, Billerica, MA, USA) equipped with UV laser ( $336 \mathrm{~nm}$ ). The range of positive ions was recorded from 500 up to $8000 \mathrm{Da}$.

Flow cytometry. Ploidy analyses of Ehrlich carcinoma and normal peritoneal cells were done by flow cytometry (FACScan, Becton Dickinson, San Jose, CA, USA). Mice with i.p. transplanted Ehrlich carcinoma cells received HAP or blood serum (100 $\mu \mathrm{g}$ /mouse in $400 \mu 10.9 \% \mathrm{NaCl}$ solution) 7 days after tumor transplantation. After $24 \mathrm{~h}$ of injection, an aliquot 


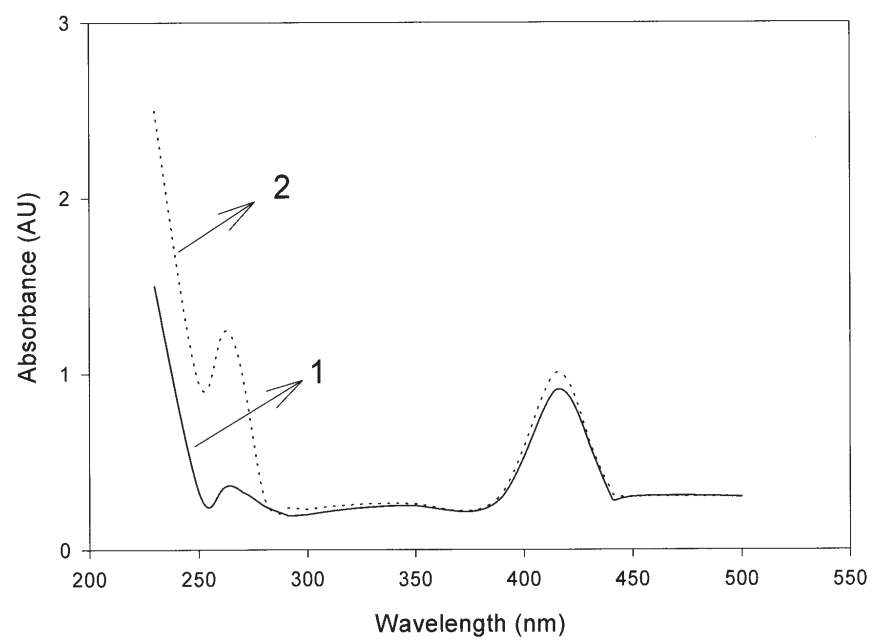

Figure 2. Absorbance of hemoglobin (1) and hemoglobin-containing complexes (2). X-axis, wave length (nm); Y-axis, absorbance (relative units). The absorption values for the hemoglobin-protein complex of tumorbearing animals were 1.2 at $\lambda=280 \mathrm{~nm}$ and $\mathrm{A}_{414 \mathrm{~nm}}=1.0$ (relative units) with a ratio of $\mathrm{A}_{280 \mathrm{~nm}} / \mathrm{A}_{414 \mathrm{~nm}}=1.2$, while the absorption values for non-complex hemoglobin of healthy mice were $A_{280 \mathrm{~nm}}=0.33$ and $\mathrm{A}_{414 \mathrm{~nm}}=0.90$, respectively (ratio $\mathrm{A}_{280 \mathrm{~nm}} / \mathrm{A}_{414 \mathrm{~nm}}=0.37$ ). This experiment was repeated 5 times

of ascitic liquid was aspirated and centrifuged at $800 \mu \mathrm{g}$ in physiological solution for $10 \mathrm{~min}$. Ascites was fixed in $70 \%$ ethyl alcohol and stored at $-20^{\circ} \mathrm{C}$. The cells were re-suspended in physiological solution. Normal peritoneal cells were treated in the same way and used as a control.

For staining, propidium iodide (Sigma, Deisenhofen, Germany) was added at a final concentration of $1 \mu \mathrm{g} / \mathrm{ml}$. Flow cytometry results were obtained from 10,000 cells collected in the gate set by combination of forward and side light scatters. The results were analyzed by means of the WINMDI 2.8 software.

For annexin V staining, cells were harvested and washed in physiological solution. Then, $1 \times 10^{6}$ cells were incubated with FITC-labeled annexin V (AnnexinV kit; Caltag Laboratories/ Invitrogen, Carlsbad, CA, USA) and propidium iodide ( $1 \mu \mathrm{g} /$ $\mathrm{ml}$ ) for $15 \mathrm{~min}$ at room temperature and subjected to flow cytometry as described above.

DNA fragmentation assay. Ascitic Ehrlich carcinoma cells were taken from mice and washed 3 times and resuspended in physiological solution. In control groups, normal peritoneal cells from healthy mice were washed and re-suspended in physiological solution. DNA was extracted according to a previously described protocol, subjected to $1 \%$ agarose gel electrophoresis, and stained with $1 \mu \mathrm{g} / \mathrm{ml}$ ethidium bromide (Sigma) (21).

\section{Results}

We transplanted mice i.m. with Ehrlich carcinoma cells. After the tumors reached a size of $\sim 1 \mathrm{~cm}^{3}$, the animals were sacrificed and blood serum was taken. In parallel, the serum of non-transplanted healthy mice was taken as control. Each group contained 10 animals. In Fig. 1, the elution profiles of hemoglobin from blood serum of healthy and tumor-bearing

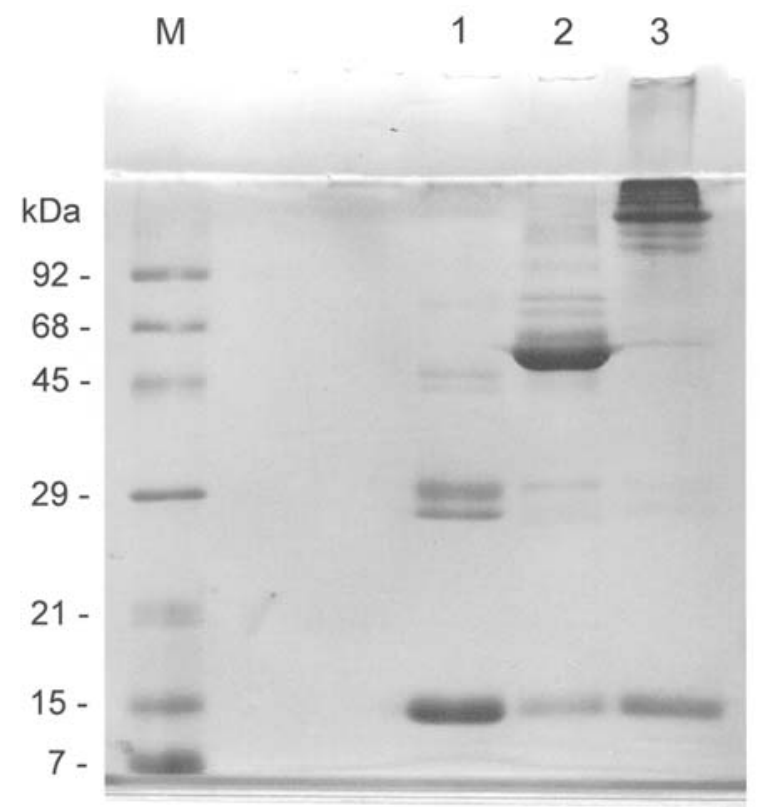

Figure 3. Gel electrophoresis of blood sera from healthy mice (lane 1) and ascitic Ehrlich carcinoma-bearing mice (lanes 2 and 3). Protein samples of lanes 1 and 2 were prepared in the presence of 2-mercaptoethanol, whereas protein sample of lane 3 did not contain 2-mercaptoethanol. Molecular weight standards are also shown. A representative gel electrophoresis of 3 independent experiments is shown.

mice after ion exchange chromatography with Sephadex QFF columns are shown. Hemoglobin of healthy animals was eluted with in a total volume of $10( \pm 1) \mathrm{ml}$ (Fig. 1A), whereas the volume required eluting hemoglobin from tumor-bearing mice was $160( \pm 3) \mathrm{ml}$ (Fig. 1B). This indicates either a change of charge of hemoglobin or formation of hemoglobin complexes.

Then, we separated proteins from Ehrlich carcinomabearing and healthy control mice by gel filtration with HW55F columns. Hemoglobin of tumor-bearing mice was eluted in a volume of $155( \pm 5) \mathrm{ml}(\mathrm{n}=10)$, whereas hemoglobin of healthy animals was eluted in $190( \pm 5) \mathrm{ml}(\mathrm{n}=10)$, indicating that proteins or associations of proteins of different molecular size were present in the samples from tumor-bearing and healthy mice. The elution volumes corresponded to proteins with molecular weights of 60 and $310 \mathrm{kDa}$, respectively. The proteins identified had different optical densities at $\lambda=280 \mathrm{~nm}$ and $\lambda=414 \mathrm{~nm}$ in spectrophotometry (Fig. 2).

To study the proteins of the blood sera, we performed gel electrophoresis (Fig. 3). The hemoglobin fractions isolated from the serum of the healthy mice contained protein bands at $15 \mathrm{kDa}$, a double band at $30 \mathrm{kDa}$ and a faint double band at $45 \mathrm{kDa}$ (Fig. 3, lane 1). The hemoglobin fractions isolated from the serum of mice bearing tumors contained several proteins with molecular weights of 15,65 , and $68-100 \mathrm{kDa}$ (Fig. 3, lane 2). Since high molecular weight proteins such as haptoglobin can associate with other proteins to form complexes of various molecular weight (22), which could be dissociated in standard sample buffer containing 2-mercaptoethanol, we also used sample buffer without 2-mercaptoethanol for protein samples of mice bearing Ehrlich carcinoma. Whereas 2-mercaptoethanol-free protein samples contained 

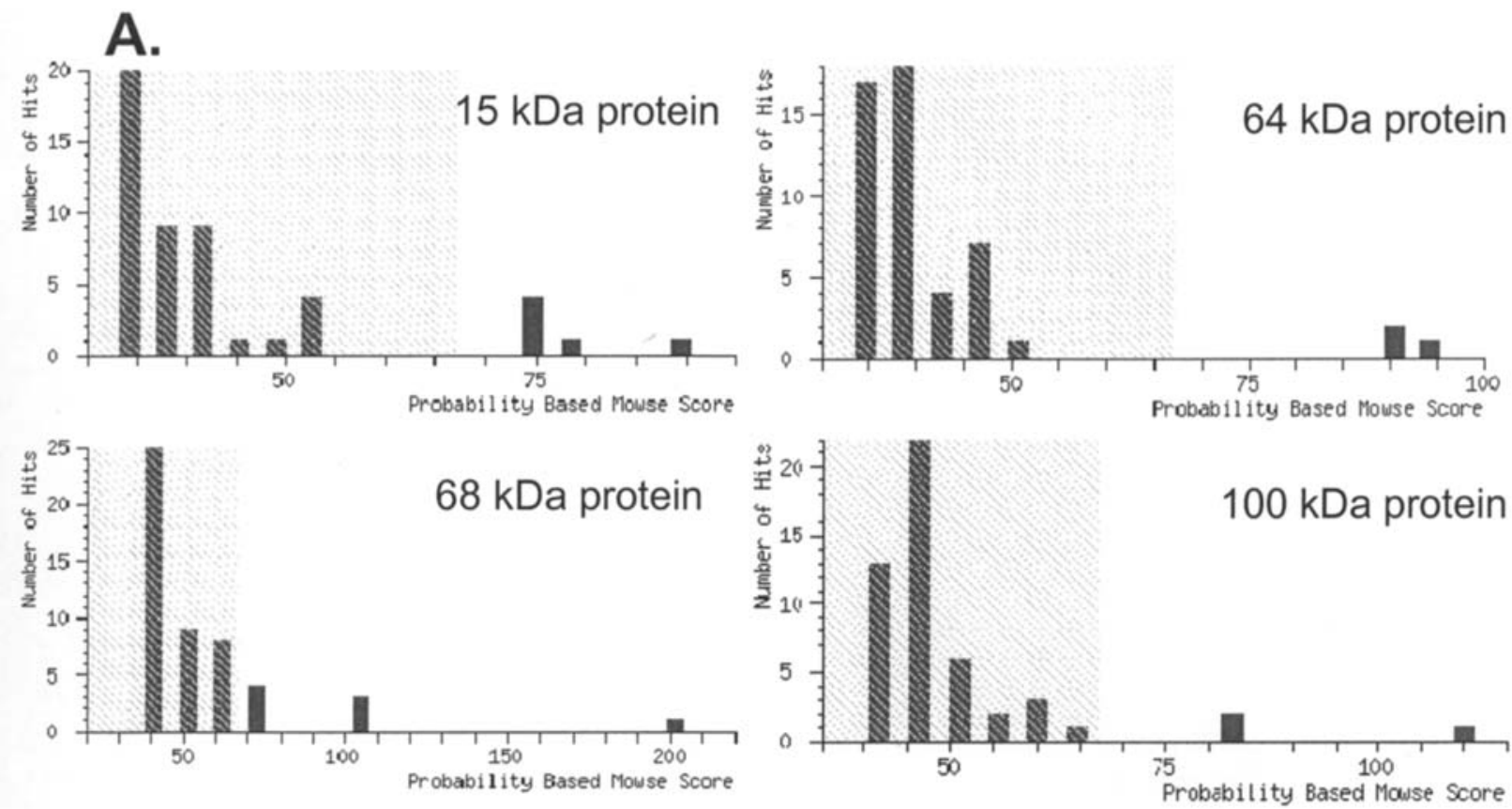

B.

1 ESVLTPPPLG APEAPEPEPP PADDSPAEPE PRAVGRTNHL SLPRFAPVVT

51 TPVKAEVSPH GAPALSNGPQ TQAQLLQPLQ ALQTQLLPQA LPPPQPQLQP 101 PPSPQQMPPL EKARIAGVGS LPLSGVEEKM FSLLKRAKVQ LFKIDQQQQQ 151 KVAASMPLSP GGQMEEVAGA VEQISDRGPV RSEDESVEAK RERPSGPESP 201 VQGPRIKHVC RHAAVALGQA RAMVPEDVPR LSALPLRDRQ DLATEDTSSA 251 SETESVPSRS RRGKVEAAGP GGESEPTGYG GTLAHTPRRS LPSHHGKKMR 301 MARCGHCRGC LRVQDCGSCV NCLDKPKFGG PNTKKQCCVY RKCDKIEARK 351 MERLAKKGRT IVKTLLPWDS DESPEASPGP PGPRRGAGAG GPREEVVAHP 401 GPEEQDSLLQ RKSARRCVKQ RPSYDIFEDS DDSEPGGPPA PRRRTPRENE 451 LPLPEPEEQS RPRKPTLQPV LQLKARRRLD KDALAPGPFA SFPNGWTGKQ 501 KSPDGVHRVR VDFKEDCDLE NVWLMGGLSV LTSVPGGPPM VCLLCASKGL 551 HELVFCQVCC DPFHPFCLEE AERPLPQHHD TWCCRRCKFC HVCGRKGRGS 601 KHLLECERCR HAYHPACLGP SYPTRATRKR RHWICSACVR CKSCGATPGK 651 NWDVQWSGDY SLCPRCTQLY EKGNYCPICT RCYEDNDYES KMMQCAQCDY 701 WVHAKCEGLS DEDYEILSGL PDSVLYTCGP CAGAAQPRWR EALSGALQGG 751 LRQVLQGLLS SKVVGPLLLC TQCGPNGKQL HPGPCGLQAV SQRFEDGHYK 801 SVHSFMEDMV GILMRHSEEG ETPDRRAGGQ MKGLLLKLLE SAFGWFDAHD 851 PKYWRRSTRL PNGVLPNAVL PPSLDHVYAQ WRQQEPETPE SGQPPGDPSA 901 AFQGKDPAAF SHLEDPRQCA LCLKYGDADS KEAGRLLYIG QNEWTHVNCA 951 IWSAEVFEEN DGSLKNVHAA VARGRQMRCE LCLKPGATVG CCLSSCLSNF 1001 HFMCARASYC

Figure 4. Identification of proteins by MALDI-TOF. (A) Probability-based mowse scores of MALDI-TOF spectra for 15, 64, 68, and 100 kDa proteins. (B) Amino acid sequence of hemoglobin- $\alpha$ (15 kDa protein). Matched peptides shown in bold. Ions score is $-10 * \log (\mathrm{P})$, where $\mathrm{P}$ is the probability that the observed match is a random event. Protein scores $>67$ are significant $(\mathrm{p}<0.05)$. This experiment was repeated 3 times.

protein bands of $\sim 310 \mathrm{kDa}$ (Fig. 3, lane 3) indicative for protein complexes, these bands were not visible in 2-mercaptoethanol containing protein samples (Fig. 3, lane 2). Instead, several smaller bands between 50 and $300 \mathrm{kDa}$ appeared indicating that the high molecular weight complexes are broken.

To identify the proteins in the sera of tumor-bearing mice found gel electrophoresis, we applied MALDI-TOF MS analysis. The double band with a molecular weight of $\sim 15 \mathrm{kDa}$ was identified as hemoglobin- $\alpha$. The $65 \mathrm{kDa}$ band was noted as gil26341396 unknown protein (Mus musculus) with homology to $\alpha$-fetoprotein. The band at $68 \mathrm{kDa}$ was found to be serum albumin, and the $100 \mathrm{kDa}$ band was identified as haptoglobin (Table I). Probability based mowse score MALDI-TOF spectra for serum protein are shown in Fig. 4. The double band of $30 \mathrm{kDa}$ in serum of healthy mice, which was only faint in serum of tumor-bearing mice, was identified 
Table I. MALDI-TOF- mass spectrometry of proteins forming a complex with hemoglobin.

Molecular weights of protein bands

in gel electrophoresis

Accession Mass (Da)

Description

\begin{tabular}{rlll}
\hline $100 \mathrm{kDa}$ & Gil8850219 & 38727 & Haptoglobin \\
$68 \mathrm{kDa}$ & gil33859506 & 68678 & Serum albumin \\
$64 \mathrm{kDa}$ & gil26341396 & 64961 & Homologue of $\alpha$-fetoprotein \\
$15 \mathrm{kDa}$ & Gil6680175 & 15076 & Hemoglobin- $\alpha$ \\
\hline
\end{tabular}
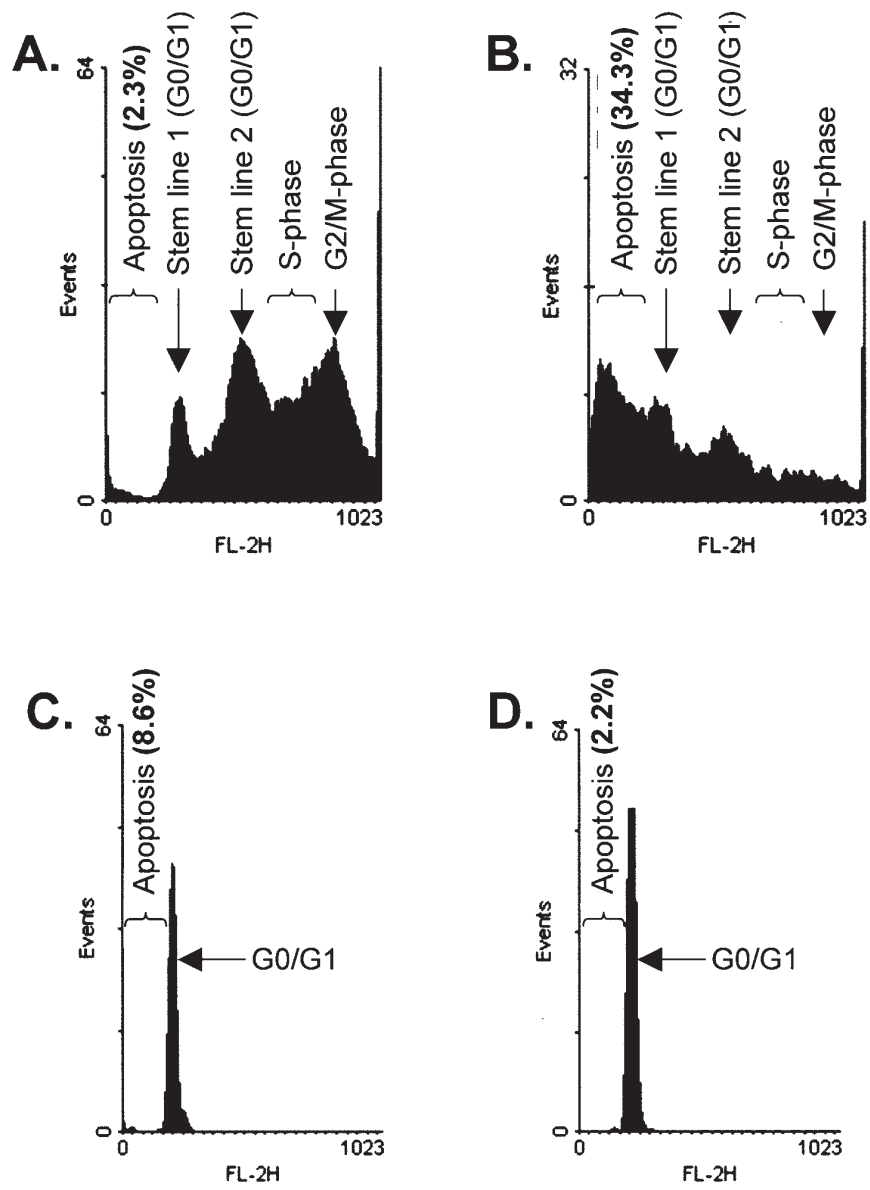

Figure 5. Propidium iodide staining and flow cytometric analysis of ascitic Ehrlich carcinoma cells (A and B) and normal peritoneal cells (C and D). (A) DNA histogram of ascitic Ehrlich carcinoma cells of mice without HAP injection. (B) DNA histogram of ascitic Ehrlich carcinoma cells of mice $24 \mathrm{~h}$ after HAP injection $(100 \mu \mathrm{g})$. (C) DNA histogram of normal peritoneal cells of mice without HAP injection. (D) DNA histogram of normal peritoneal cells of mice $24 \mathrm{~h}$ after HAP injection $(100 \mu \mathrm{g})$. X-axis, fluorescence intensity at FL-2H (relative units) and Y-axis, events. Representative histograms and gel electrophoreses of three independent experiments are shown.

as dimeric hemoglobin. The thin bands of $45 \mathrm{kDa}$ in serum of healthy mice represent trimeric hemoglobin.

To investigate functional aspects of these serum components, we injected HAP i.p. from tumor-bearing mice into recipient mice, which carried ascitic Ehrlich carcinoma cells, and performed flow cytometric measurements (Fig. 5). In tumor-bearing mice without HAP injection, Ehrlich carcinoma cells were highly proliferating with a large portion of cells in the $\mathrm{S} / \mathrm{G} 2 / \mathrm{M}$ cell cycle phases. As the ELD strain of Ehrlich carcinoma is aneuploid with two different stem lines, it was difficult to dissect the different cell cycle phase to determine the percentage of their cell cycle fractions (Fig. 5A). The fraction of sub-G1 Ehrlich carcinoma cells was $2.8 \pm 0.5 \%$ in mice without HAP inoculation $(n=3)$. Upon HAP injection, the fraction of proliferating cells decreased, and $33.4 \pm 1.1 \%$ of tumor cells appeared in the sub-G1 fraction indicating tumor cell death (Fig. 5B). For control, $50 \mu 1$ blood serum of healthy mice was injected into tumor-bearing mice, and no increase of the sub-G1 fraction of Ehrlich carcinoma cells was observed.

Then, we analyzed diploid normal peritoneal cells by flow cytometry. Normal peritoneal cells from mice inoculated with or without HAP did not undergo apoptosis indicating that HAP are inactive against normal peritoneal cells (Fig. 5C and D). Hence, normal peritoneal cells can serve as a negative control for the specificity of the reaction of HAP against tumor cells. Furthermore, normal peritoneal cells did not show a growth fraction (S/G2/M cells).

The results of the propidium iodide staining indicated that HAP injection induces apoptosis in ascitic Ehrlich carcinoma cells, but not in normal peritoneal cells. To prove this in more detail, we applied annexin-V staining and flow cytometry. As shown in Fig. 6, 37.2\% ascitic Ehrlich carcinoma cells were apoptotic after HAP injection (Fig. 6B), whereas only $0.4 \%$ apoptotic cells were found in untreated ascitic Ehrlich carcinoma control cells (Fig. 6A). For control, $50 \mu 1$ blood serum of healthy mice was injected into tumor-bearing mice. No increase of the apoptotic fraction of ascitic Ehrlich carcinoma cells was observed compared to untreated mice. Furthermore, HAP injection did not lead to apoptosis induction in normal peritoneal cells compared to untreated peritoneal cells (Fig. 6C and D).

Furthermore, we investigated apoptosis by means of a DNA fragmentation assay. Typical apoptosis-associated DNA laddering was only found in HAP-treated ascitic Ehrlich carcinoma cells (Fig. 6E, lane 2), but not in untreated ascitic Ehrlich carcinoma cells (Fig. 6E, lane 1) nor in untreated and HAP-treated normal peritoneal cells (Fig. 6E, lanes 3 and 4).

As found by microscopic analysis, application of HAP to mice increased the size of ascitic Ehrlich carcinoma cells and induced vacuolization (Fig. 7A and B). The size of peritoneal cells was not changed by HAP injection, and vacuolization was not present in these cells (Fig. 7C and D).

We assessed the role of HAP for the regulation of tumor growth in vivo. HAP injection to mice with i.p. transplanted 
A.

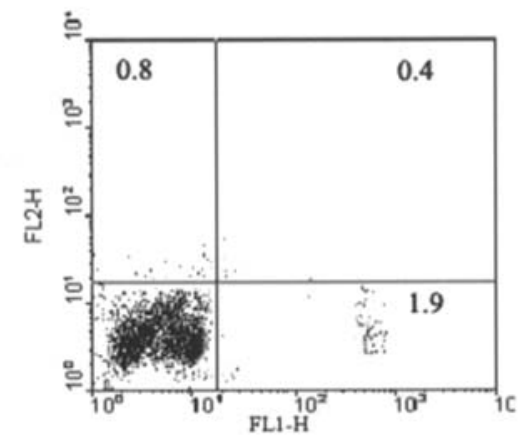

C.

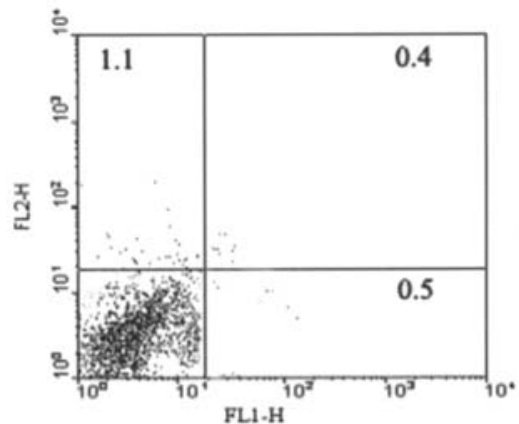

B.

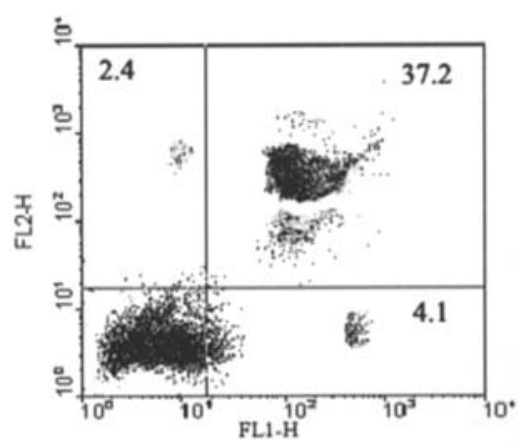

D.

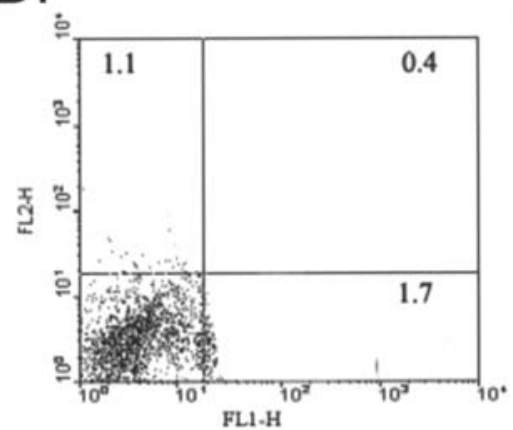

E.

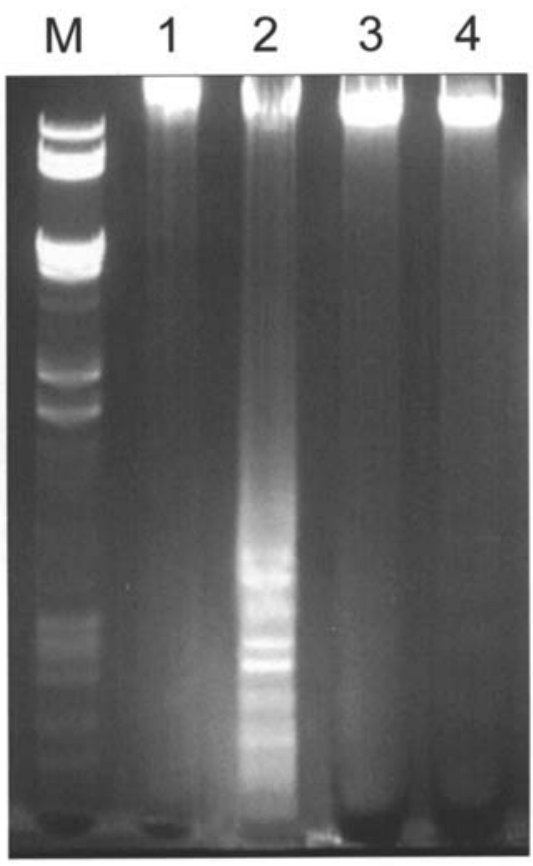

Figure 6. Detection of apoptosis in ascitic Ehrlich carcinoma cells and normal peritoneal cells with or without HAP injection. Annexin-V FITC staining and flow cytometric analysis (A-D): (A) Ascitic Ehrlich carcinoma cells of mice without HAP injection. (B) Ascitic Ehrlich carcinoma cells of mice 24 h after HAP injection (100 $\mu \mathrm{g})$. (C) Normal peritoneal cells of mice without HAP injection. (D) Normal peritoneal cells of mice $24 \mathrm{~h}$ after HAP injection (100 $\mu \mathrm{g})$. DNA fragmentation (E): M, molecular weight standard (Lambda/HindIII, 125, 564, 2027, 2322, 4361, 6557, 9416, and 23130 bp). 1, Ascitic Ehrlich carcinoma cells of mice without HAP injection. 2, Ascitic Ehrlich carcinoma cells of mice $24 \mathrm{~h}$ after HAP injection (100 $\mu \mathrm{g}) .3$, Normal peritoneal cells of mice without HAP injection. 4, Normal peritoneal cells of mice with HAP injection (100 $\mu \mathrm{g})$. Representative histograms and gel electrophoreses of three independent experiments are shown.

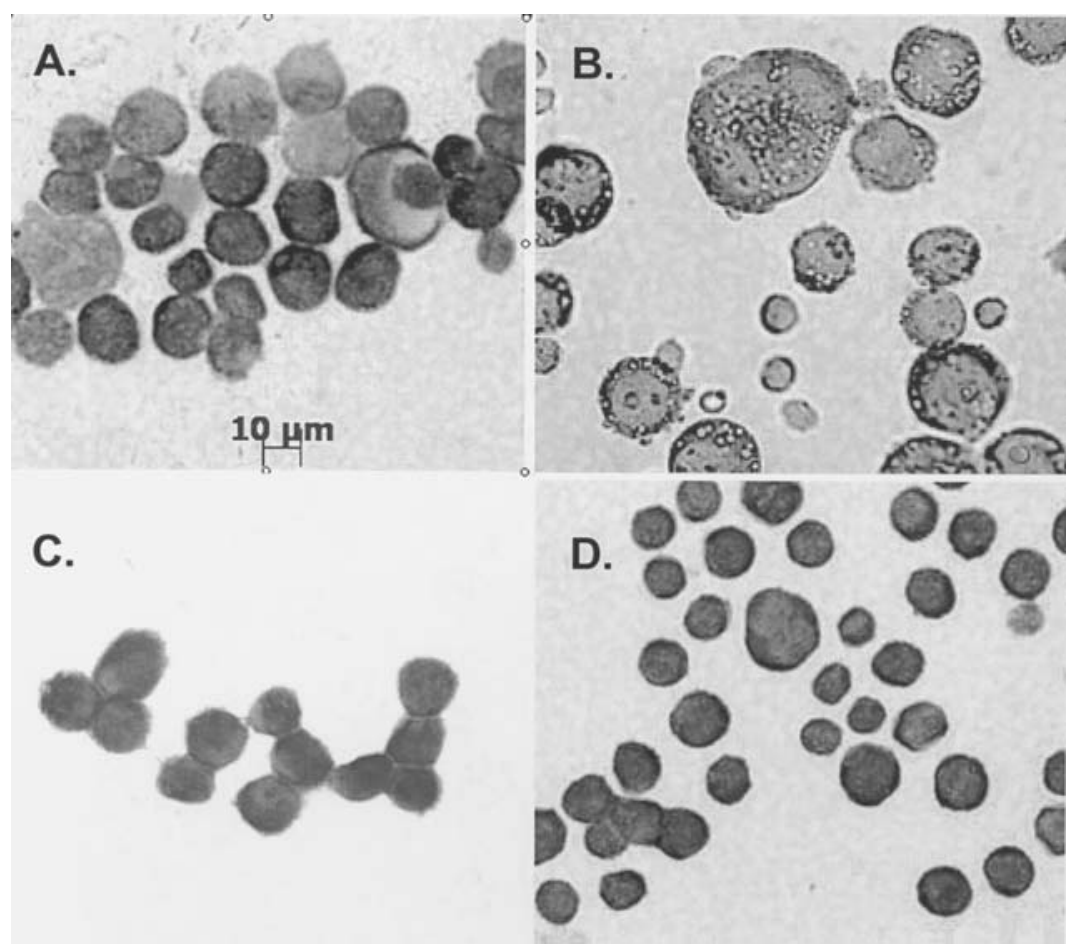

Figure 7. Microscopy of hematoxylin-eosin stained Ehrlich carcinoma cells and normal peritoneal cells (magnification x900). (A) Ascitic Ehrlich carcinoma cells of mice without HAP injection. (B) Ascitic Ehrlich carcinoma cells of mice $24 \mathrm{~h}$ after HAP injection (100 $\mu \mathrm{g}$ ). (C) Normal peritoneal cells of mice without HAP injection. (D) Normal peritoneal cells of mice $24 \mathrm{~h}$ after HAP injection (100 $\mu \mathrm{g})$. Representative images of three independent experiments are shown. 
Table II. Effect of hemoglobin-associated proteins (HAP) on survival of mice with transplanted Ehrlich carcinoma.

\begin{tabular}{|c|c|c|c|}
\hline Group & Manipulation & $\begin{array}{l}\text { Average mouse } \\
\text { survival (days) }\end{array}$ & $\begin{array}{l}\text { Significance } \\
\text { (p-value) }\end{array}$ \\
\hline 1 & $\begin{array}{l}\text { Ehrlich carcinoma transplanted } \\
\text { intraperitoneally }\end{array}$ & $19.8+1.2$ & \\
\hline 2 & $\begin{array}{l}\text { Ehrlich carcinoma transplanted } \\
\text { intraperitoneally + blood serum }\end{array}$ & $20.2+1.4$ & $\begin{array}{r}>0.5^{\mathrm{a}} \\
\mathrm{NS}\end{array}$ \\
\hline 3 & $\begin{array}{l}\text { Ehrlich carcinoma transplanted } \\
\text { intraperitoneally + HAP }\end{array}$ & $>365$ days & $<0.001^{\mathrm{a}}$ \\
\hline 4 & $\begin{array}{l}\text { Ehrlich carcinoma transplanted } \\
\text { intramuscularly }\end{array}$ & $59.6+1.7$ & \\
\hline 5 & $\begin{array}{l}\text { Ehrlich carcinoma transplanted } \\
\text { intramuscularly + blood serum }\end{array}$ & $60.1+1.5$ & $\begin{aligned}>0.5^{\mathrm{b}} \\
\mathrm{NS}\end{aligned}$ \\
\hline 6 & $\begin{array}{l}\text { Ehrlich carcinoma transplanted } \\
\text { intramuscularly + HAP }\end{array}$ & $>365$ days & $<0.001^{\mathrm{b}}$ \\
\hline
\end{tabular}

aSignificant differences between the groups 1 vs 2 , and 1 vs 3 . 'bignificant differences between the groups 4 vs 5 , and 4 vs 6 . NS, not significant. Each group contained 10 animals.

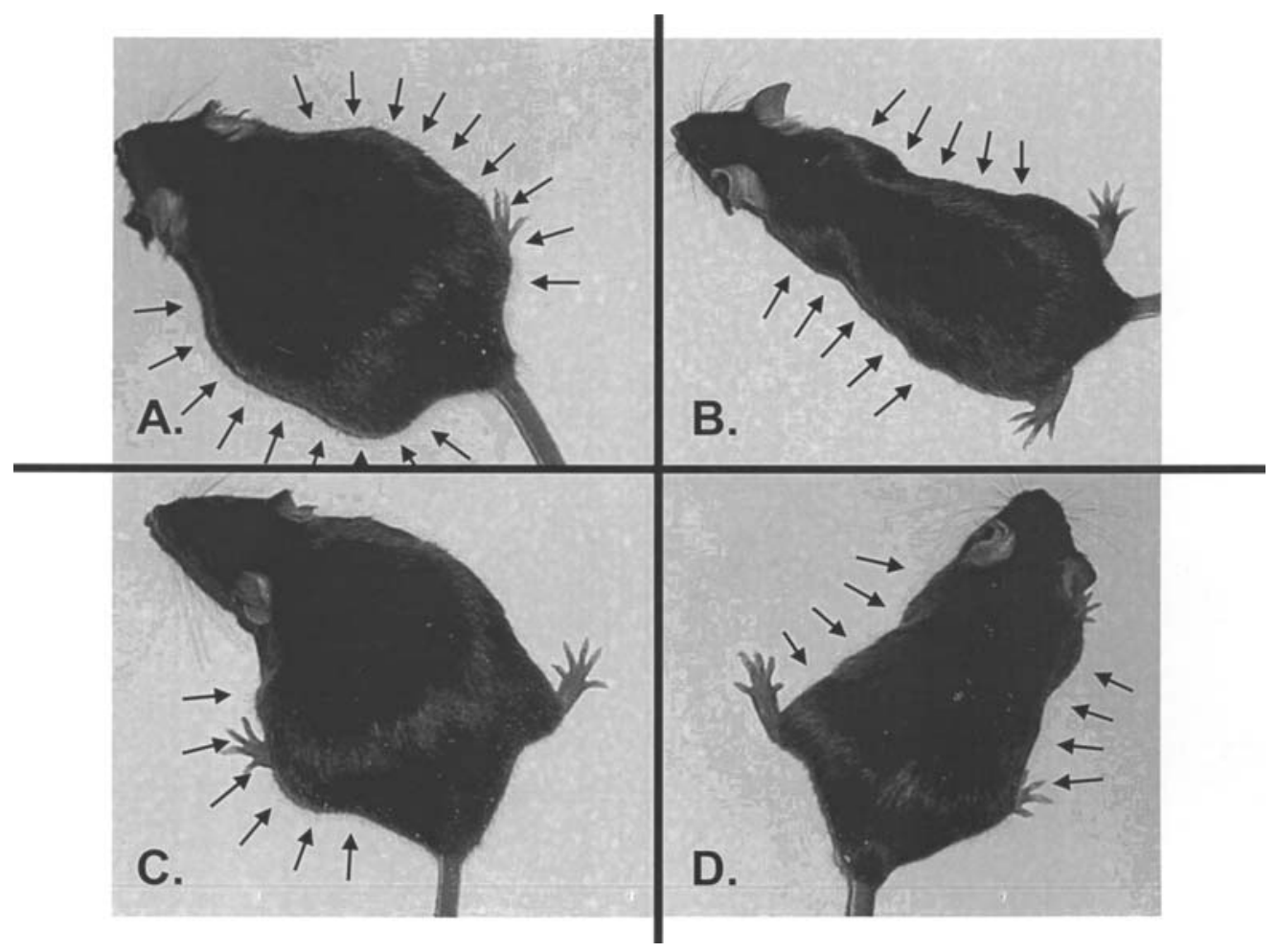

Figure 8. Ehrlich carcinoma-bearing mice with and without HAP treatment. (A) Mouse with untreated ascites tumor at day 12 after tumor cell inoculation. (B) Mouse with ascites tumor at day 12 after tumor cell inoculation and $24 \mathrm{~h}$ after HAP injection $(100 \mu \mathrm{g})$. (C) Mouse with untreated solid tumor at day 12 after tumor cell inoculation. (D) Mouse with solid tumor at day 12 after tumor cell inoculation $24 \mathrm{~h}$ after HAP injection (100 $\mu \mathrm{g})$. Representative images of 10 independent experiments are shown.

Ehrlich carcinoma led to a complete regression of the ascites (Table II). The same applies for solid tumors after injection of Ehrlich carcinoma cells i.m. (Table II).
When these animals, cured by HAP injection of their tumor disease, were challenged by repeated tumor transplantation, tumors did not grow, even if the cell number 
of transplanted cells was increased from $1 \times 10^{6}$ to $40 \times 10^{6}$ cells/mouse) (Fig. 8). The follow-up observation of the animals continued for a year and post mortem examination did not reveal any signs of tumor growth.

\section{Discussion}

In the present study, we analyzed serum proteins of mice bearing Ehrlich carcinoma cells and compared them with mice without tumors. We found that hemoglobin associated with serum proteins of tumor-bearing animals that had a molecular weight of $300 \mathrm{kDa}$. The association included proteins having lower molecular weights of 15, 65, 68 and $100 \mathrm{kDa}$, respectively (hemoglobin- $\alpha$, homologue of $\alpha$-fetoprotein (AFP), serum albumin, and haptoglobin). While these complexes did not break up in column chromatography, they were dissociated in sample buffer containing 2-mercaptoethanol. Haptoglobin is known to form various high molecular weight complexes (22). In normal blood serum of mice, hemoglobin did not form a complex with haptoglobin, because haptoglobin is only present in serum of tumor-bearing mice. This result is consistent with observations that specific proteins are solely present in plasma of tumor-bearing mice, e.g., haptoglobin, proteosome subunits, fetuin-B, 14-3-3 $\zeta$, MAGE-B4 antigen and others (23). In healthy mice, prevalent protein bands were found at 15,30 , and $45 \mathrm{kDa}$, which represent monomeric, dimeric and trimeric hemoglobin (24).

This indicates that not a single protein but associations of proteins might reveal biological activity. These results extend our previous studies on complex formation among serum proteins $(7,25)$. We speculate that the different complex formations are due to changes in protein glycosylation during tumor growth. Protein glycosylation is important for the charge and spatial structure of protein, and, hence, for their interaction with each other. On the other hand, large molecular complexes are unlikely to be formed in blood serum, because they might disturb blood flow characteristics and physiology. Therefore, it is possible that protein complexes are formed between intracellular proteins (when they appear in blood serum after tumor cell destruction) and constitutive blood serum proteins in tumor-bearing but not in healthy mice. The most significant protein in terms of amount in blood is hemoglobin (26). Therefore, it can be assumed that protein associations are formed with hemoglobin.

Injection of HAP to animals with transplanted Ehrlich carcinoma caused tumor regression without recurrences or metastases. HAP led to an induction of apoptosis in tumor cells. However, it is still not clear, which of the proteins are responsible for the anti-tumor effect. Humoral factors in mouse blood serum may account for the observed tumor progression $(8,25)$.

It is well known that blood serum contains proteins such as haptoglobins, which form associations with hemoglobin. These associations alter hemoglobin metabolism pathways and the formation of tissue peptide pools, especially in injured tissues and organs (17). Differences in hemoglobin metabolism of healthy and tumor-bearing animals have to be considered as well. A differential hemoglobin metabolism may be associated with post-translational modifications such as altered protein glycosylation patterns in tumor-bearing organisms. This may result in a different interaction of proteins (7), and protein associations formed in healthy subjects may differ from those in tumor-bearing animals.

We found hemoglobin associated with a homologue to AFP by means of MALDI-TOF. AFP is able to induce apoptosis in tumor cells $(27,28)$. The molecular mechanisms are at least partly elucidated. AFP-mediated apoptosis signals bypass Fas-dependent and tumor necrosis factor receptordependent signaling routes and lead to cytochrome c release, cytochrome c/dATP-mediated apoptosome complex formation, and caspase- 3 and -9 activation $(27,29)$. Furthermore, AFP interacts with X-linked inhibitor of apoptosis protein (XIAP) and blocks the binding of XIAP to caspase-3 (30). XIAP suppresses caspase- 3 activity. We speculate that one of the humoral factors leading to tumor regression upon HAP injection in our study may be a complex of hemoglobin and the AFP homologue identified. Another mechanism independent from the apoptosis-inducing effects is the stimulation of anti-tumor immune response. AFP enhances the dendritic-cell-mediated immune reaction of T-lymphocytes against tumor cells $(31,32)$. It is intriguing that AFP isolated from human cord serum has been shown to inhibit the growth of human hepatocarcinoma cells (33). This approach is comparable to ours and speaks for our hypothesis.

Whether complexes of hemoglobin with other serum proteins also play a role in suppression of tumor growth requires further investigation. Hemoglobin-haptoglobin complexes have been described to induce apoptosis of hepatocarcinoma cells (34). An anti-tumor effect in our Ehrlich carcinoma model can, therefore, also be discussed. It is also possible that hemoglobin itself contributes to anti-tumor effects, since hemoglobin can mediate cytotoxicity and apoptosis towards tumor cells in a fashion similar to tumor necrosis factor- $\alpha$ (35).

The phenomenon observed by us in mice with i.p. or i.m. transplanted Ehrlich carcinoma requires extended studies in other experimental models. This phenomenon merits further investigation in clinical settings. In analogy to chemoprevention, the concept of immunoprevention has been developed as an approach to prevent cancer based on the stimulation of the immune system before tumor onset (36). It is not beyond the limits of expectations that blood serum from tumor-bearing subjects can be used not only for the treatment but also for the serological prevention of relapse of tumors (seroprevention). The full exploration of underlying mechanisms will be important to the development of novel treatment strategies in oncology.

\section{Acknowledgements}

We would like to thank Drs Dieter Kübler and Stefan Herzig (German Cancer Research Center, Heidelberg) for critical reading of the manuscript.

\section{References}

1. Fisher B, Gunduz N, Coyle J, Rudock C and Saffer E: Presence of a growth-stimulating factor in serum following primary tumor removal in mice. Cancer Res 49: 1996-2001, 1989.

2. Mitchison NA: Passive transfer of transplantation immunity. Proc R Soc Lond B Biol Sci 142: 72-87, 1954. 
3. Klein G, Sjbgren HO, Klein E and Hellström KE: Demonstration of resistance against methylcholanthrene-induced sarcomas in the primary autochthonous host. Cancer Res 20: 1561-1572, 1960.

4. Winn HJ: The immune response and the homograft reaction. Natl Cancer Inst Monogr 2: 113-138, 1960.

5. Dudley ME and Rosenberg SA: Adoptive-cell-transfer therapy for the treatment of patients with cancer. Nat Rev Cancer 3: 666-675, 2003.

6. Donenko FV, Sitdikova SM, Kabieva AO and Moroz LV: The characteristics of Ehrlich carcinoma recurrence and metastasis. Biull Eksp Biol Med 114: 652-654, 1992 (in Russian).

7. Sitdikova SM, Amandzholov BS, Sel'chuk VY and Donenko FV: Tumor-specific changes in mouse serum during Ehrlich carcinoma growth. Bull Exp Biol Med 135: 576-579, 2003.

8. Freitas I, Fracchiolla S, Baronzio G, Griffini P, Bertone R, Sitar GM, Barni S, Gerzeli G and Sacco MG: Stem cell recruitment and liver de-differentiation in MMTV-neu (ErbB-2) transgenic mice. Anticancer Res 23: 3783-3794, 2003.

9. Bennett JA, Semeniuk DJ, Jacobson HI and Murgita RA: Similarity between natural and recombinant human alphafetoprotein as inhibitors of estrogen-dependent breast cancer growth. Breast Cancer Res Treat 45: 169-179, 1997.

10. Bennett JA, Mesfin FB, Andersen TT, Gierthy JF and Jacobson HI: A peptide derived from alpha-fetoprotein prevents the growth of estrogen-dependent human breast cancers sensitive and resistant to tamoxifen. Proc Natl Acad Sci USA 99: 2211-2215, 2002.

11. Vakharia D and Mizejewski GJ: Human alpha-fetoprotein peptides bind estrogen receptor and estradiol, and suppress breast cancer. Breast Cancer Res Treat 63: 41-52, 2000

12. Wang XW and Xu B: Stimulation of tumor-cell growth by alpha-fetoprotein. Int J Cancer 75: 596-599, 1998.

13. Mizejewski GJ, Dias JA, Hauer CR, Henrikson KP and Gierthy J: alpha-fetoprotein derived synthetic peptides: assay of an estrogen-modifying regulatory segment. Mol Cell Endocrinol 118: 15-23, 1996.

14. Mizejewski GJ: Alpha-fetoprotein structure and function: relevance to isoforms, epitopes, and conformational variants. Exp Biol Med 226: 377-408, 2001.

15. Mizejewski GJ, Muehlemann M and Dauphinee M: Update of alpha fetoprotein growth-inhibitory peptides as biotherapeutic agents for tumor growth and metastasis. Chemotherapy 52: 83-90, 2006.

16. Ivanov VT, Karelin AA, Philippova MM, Nazimov IV and Pletnev VZ: Hemoglobin as a source of endogenous bioactive peptides: the concept of tissue-specific peptide pool. Biopolymers 43: 171-188, 1997.

17. Ivanov VT, Yatstskin ON, Kalinina OA, Philippova MM, Karelin AA and Blishchenko E: Tissue-specific peptide pools: generation and function. Pure Appl Chem 72: 355-361, 2000.

18. Goldin A, Kline I and Sofina ZP (eds): Experimental Evaluation of Antitumor Drugs in the USA and USSR and Clinical Correlations. National Cancer Institute Monograph 55. NIH Publication no. 1933. U.S. Department of Health and Human Services. National Institutes of Health, NCI, Bethesda, MD, 1980.

19. Govorun VM, Moshkovskii SA, Tikhonova OV, Goufman EI, Serebryakova MV, Momynaliev KT, Lokhov PG, Khryapova EV Kudryavtseva LV, Smirnova OV, Toropyguine IY, Maksimov BI and Archakov AI: Comparative analysis of proteome maps of Helicobacter pylori clinical isolates. Biochemistry 68: 42-49, 2003.

20. Laemmli UK: Cleavage of structural proteins during the assembly of head of bacteriophage T4. Nature 227: 680-685, 1970.
21. Gustincich S, Manfioletti G, Del Sal G, Schneider C and Carninci P: A fast method for high-quality genomic DNA extraction from whole human blood. Biotechniques 302: 298-300, 1991

22. Scott TA and Mercer EI: Concise Encyclopedia of Biochemistry. Walter de Gruyter, Berlin - New York, keyword: Haptoglobin, pp198, 1983 .

23. Bhat VB, Choi MH, Wishnok JS and Tannenbaum SR: Comparative plasma proteome analysis of lymphoma-bearing SJL mice. J Proteome Res 4: 1814-1825, 2005.

24. Berg JM, Tymoczko JL and Stryer L: Biochemistry. 6th edition, WH Freeman and Company, 2007.

25. Donenko FV, Sitdikova SM and Moroz LV: The role of serum humoral factors in metastasis and recurrence of Ehrlich carcinoma in mice. Biull Eksp Biol Med 124: 443-445, 1997 (in Russian).

26. Dudich E, Semenkova L, Dudich I, Gorbatova E, Tochtamisheva N, Tatulov E, Nikolaeva M and Sukhikh G: alpha-fetoprotein causes apoptosis in tumor cells via a pathway independent of CD95, TNFR1 and TNFR2 through activation of caspase-3-like proteases. Eur J Biochem 266: 750-761, 1999.

27. Dudich E, Semenkova L, Gorbatova E, Dudich I, Khromykh L, Tatulov E, Grechko G and Sukhikh G: Growth-regulative activity of human alpha-fetoprotein for different types of tumor and normal cells. Tumour Biol 19: 30-40, 1998.

28. Semenkova L, Dudich E, Dudich I, Tokhtamisheva N, Tatulov E, Okruzhnov Y, Garcia-Foncillas J, Palop-Cubillo JA and Korpela T: alpha-fetoprotein positively regulates cytochrome c-mediated caspase activation and apoptosome complex formation. Eur $\mathbf{J}$ Biochem 270: 4388-4399, 2003.

29. Dudich E, Semenkova L, Dudich I, Denesyuk A, Tatulov E and Korpela T: alpha-fetoprotein antagonizes X-linked inhibitor of apoptosis protein anticaspase activity and disrupts XIAP-caspase interaction. FEBS J 273: 3837-3849, 2006.

30. Gonzalez-Carmona MA, Marten A, Hoffmann P, Schneider C, Sievers E, Schmidt-Wolf IG, Sauerbruch T and Caselmann WH: Patient-derived dendritic cells transduced with an $\alpha$-fetoproteinencoding adenovirus and co-cultured with autologous cytokineinduced lymphocytes induce a specific and strong immune response against hepatocellular carcinoma cells. Liver Int 26: 369-379, 2006.

31. Cao DY, Yang JY, Dou KF, Ma LY and Teng ZH: alphafetoprotein and interleukin-18 gene-modified dendritic cells effectively stimulate specific type-1 CD4- and CD8-mediated T-cell response from hepatocellular carcinoma patients in vitro. Hum Immunol 68: 334-341, 2007.

32. Semenkova LN, Dudich EI and Dudich IV: Induction of apoptosis in human hepatoma cells by alpha-fetoprotein. Tumour Biol 18: 261-273, 1997.

33. Kim IK, Lee JH, Kim HS, Kwon OJ and Shim BS: A novel function of haptoglobin: haptoglobin-haemoglobin complex induces apoptosis of hepatocarcinomatous Hep 3B cells. Scand J Clin Lab Invest 55: 529-535, 1995.

34. Yadav AK, Paul BN, Naik S, Saxena AK and Patel DK: Human hemoglobin shares bioactivities ascribed to human tumor necrosis factor-alpha. Immunopharmacol Immunotoxicol 26: 559-572, 2004.

35. Lollini PL, De Giovanni C, Pannellini T, Cavallo F, Forni G and Nanni P: Cancer immunoprevention. Future Oncol 1: 57-66, 2005.

36. Spisek R: Immunoprevention of cancer: time to reconsider timing of vaccination against cancer. Expert Rev Anticancer Ther 6: 1689-1691, 2006. 